\title{
NEW CONSTITUTIONAL FORMS FOR METROPOLIS: REAPPORTIONED COUNTY BOARDS; LOCAL COUNCILS OF GOVERNMENTS
}

\author{
ROBERT G. DIXON, Jr.*
}

\section{INTRODUCTION}

The most telling observation about "legal adjustment to urbanization," the assigned topic for this essay, is to note that the basic problems created by urbanization are political and constitutional. ${ }^{1}$ The problems are "legal" in the gross sense that all politics and all constitutionalism are part of law. And they are the problems of the "city" in the broad sociological sense. In this sense "city" encompasses the urbansuburban cultural whole, through which the city line runs as an artificial barrier separating homes from jobs, capacity from need, leaders from followers, managers from workers, white from black, the affluent from the poor. ${ }^{2}$ This is the true segregation problem for late Twentieth Century America. It calls for a new urban "politics of integration," to be reflected in a new civic constitution or charter for an expanded and re-integrated "city."

Concededly some of the contrasts suggested above are grossly overdrawn. But they do suggest that the common legal concept of a city as that territory bounded by a city line is a bankrupt concept. It may be as outmoded for 1965 as the military technology of $\mathrm{x} 945$, but it is not as easy to scrap city hall and make a fresh start as it is to scrap a Flying Fortress.

Cities, in the grand sense, are for people-all the people; and the problems of the people are the problems of the city. ${ }^{3}$ If the Grecian concern for the good life, conceived of as a participating citizenship in a unified social setting, has any modern locus for the great bulk of Americans it is in the metropolitanized community. It is here that are centered our problems, our concerns, and our opportunities in regard

-A.B. 1943, Ph.D. x947, Syracuse University; LL.B. 1956, George Washington University. Professor of Law, Law School and Graduate School of Public Law, The George Washington University. On leave 1964-1965, under Rockefeller Foundation Grant for legislative reapportionment research. Author, [with John R. Kerstetter] Adjusting Municipal Boundaries: The Law and Practice in 48 States (i959).

The author wishes also to acknowledge assistance from the Evening Star-George Washington University Research Fund, and student assistants Donald E. Williams and Scott A. Williams.

${ }^{1}$ Sec, e.g., ScotT A. Greer, Governing the Metropolis (1962); Robert C. Wood, Suburbia: Its People and Their Politics (1958).

a Sec Philip E. Jacob \& J. V. Toscano (Eds.), The Integration of Political Communities (1964); C. E. Elias, JR., and Others (Eds.), Metropolis: Values in Conflict (I964); Frederick I. Tietze \& J. E. McKeown (Eds.), The Changing Metropolis (I964); Blake McKelvey, The Urbanization of America (1963).

${ }^{3}$ Metropolitan governmental re-integration may be seen as a pre-condition of effective cultural and racial integration. The city has tended recently to relinquish its traditional role as the matrix of civilization as portrayed by Lewis Mumford in The City in History. It has tended to become "a reservation containing those persons who have been rejected by society and shunted away from the mainstream of American life." See Ferguson, A Brief Commentary on Urban Redevelopment and Civil Rights, 9 How. L. J. Ior, II4 (Ig63). See also Weissbourd, Segregation, Subsidies, and Megalopolis, Occasronsi PAPer No. I on the City, Center for the Study of Democratic Institutions (1964). 
to housing, education, employment, health, culture, sport, transportation, civil rights and liberties, morality, religion, family life, and even recreation. Despite the laments for the passing of the small town, there is a surprising amount of community feeling in urban America. ${ }^{4}$ Spreading over several local jurisdictions and even crossing state lines $^{5}$ there is a New York community, a Philadelphia community, a Washington community, a Chicago community, a St. Louis community. The list could be multiplied by running through the Bureau of the Census list of "standard metropolitan statistical areas." Most of the pressing problems of modern government-minus foreign relations, defense, and some aspects of interstate business-center in these areas. $^{6}$

\section{Suburban Politics and Structure}

The political and constitutional problems of urbanization appear in particularly acute form in suburban America. Suburbia tends to be a conglomeration of special districts, towns and villages, and unorganized subdivisions. This mass is held together and serviced in varying degrees by the county and is subject occasionally to extraterritorial powers of the central city. Much of suburbia tends to be a postWorld War II phenomena.

In the initial postwar flush, when new suburbia was truly like a new frontier, there was a revival of the frontier tradition of self-help, civic work, eager cooperation, and extroverted neighborliness. In many areas the political and governmental vacuum was filled by subdivision citizens' associations, which combined to form civic federations. $^{\top}$

4 This statement refers to the sense of urban identity that people tend to have, and docs not imply either a sense of satisfaction or harmony. Of dissatisfaction and disharmony there is ample evidence, going right down to the elementals of life. See, e.g., the New York police report that 34 middle-class residents watched a killer stalk Catherine Genovese for 30 minutes before he killed her, Washington Post, March 28, 1964, p. 3, col. 1 ; and the recent formation of private night guards in Brooklyn, N.Y. Times, Jan. 25, 1965, p. 34, col. 4. See also Ward, "The City May Be as Lethal as the Bomb," N.Y. Times Magazine, April $x 9,1964$, p. 22.

${ }^{B}$ Interstate metropolitan regionalism raises special problems and is not treated here. Sce JoHN M. Winters, INTERstate Metropolitan AREAs (I962); Dixon, Constitutional Bases for Regionalism: Centralization; Interstate Compacts; Federal Regional Taxation, 33 GEo. WasH. L. Rev. 47 (1964); Gove \& Silverstein, Political Representation and Interstate Urban Agencies, 17 ILl. Gov'T I (1963).

- The 216 Standard Metropolitan Statistical Areas (central city of 50,000 or more plus surrounding territory) comprise $64 \%$ of the total United States population, U.S. BurEaU of THE CENsUS, Statisticat Aastract of the United States 14-I5, 17 ( 1964$)$.

President Lyndon B. Johnson's message to Congress on housing and cities, March 2, 1965, proposed a number of programs "designed to help us begin to think and act across boundaries to enrich the life of the people of our metropolitan areas." N.Y. Times, March 3, 1965, p. 30, col. 3.

'The roles, the forms, the problems, the accomplishments of subdivision or neighborhood citizens' associations, which exist within cities as well as outside, have been studied insufficiently. As a field for political science " $\mathrm{Ph} . \mathrm{D}$. dissertation" development, they would appear to warrant serious consideration. They constitute an informal government, private in form, public in purpose. See, e.g., SIDNEX VERDA, Smati Groups and Poltticai. Behavior (196r); Schnore \& Alford, Forms of Government and Socioeconomic Characteristics of Suburbs, 8 ADMIN. ScIENCE Q. I (1963).

On community power structure in general, apart from institutional forms, see NeLson W. PotsBY, Comanumity Power and Political Theory (r963); Chas. Press, Main Street Politics (1962); Rodert A. Dafr, Who Governs? (196x); Salisbury, Urban Politics: The Netw Convergence of Polver, 26 J. Poz. 
The accomplishments of this amateur, voluntary government of citizens' associations are not to be minimized. Zoning battles were fought, and often won, to keep gas stations, soft drink bottling plants, or dog and cat hospitals from entering residential areas. (My own community in Montgomery County, Maryland, a suburb of Washington, D. C., fought and won each of the battles mentioned.) Churches were built, scouting activities proliferated, softball teams and leagues were organized. Shopping centers, bowling alleys, and small industry followed.

As the postwar years lengthened, however, the informal suburban government of citizens' associations faltered. Unpaid enthusiasm, a disposition to sacrifice endless evenings, a self-less dedication to civic betterment, cannot be maintained indefinitely. In part this form of "government" fell victim to its own success, and to the relative stabilization of suburbia. Zoning battles-and the intense community loyalty they induce in the average suburban dweller-receded as unoccupied land became scarce. And with the pressure of other community activities in the increasingly urbanized suburb, attendance at a civic association meeting, or hard work on a civic association committee, fell from first place to last place on an ever-lengthening list.

In short, the time came for the professionals, i.e., the politicians, who can develop a career interest in government, to take over. Few places, however, have met the challenge to create a party-government structure out of formless suburbia, and to develop appropriate links to the core city. Suburbia seems still to be going through a period comparable to the national experience of the r79os. Then the tired volunteers of the war period, the confederation period, the constitutional convention period, and the constitutional ratification period, finally shook down into identifiable and responsible political parties with a few readily identifiable and responsible fulltime leaders. Suburbia is still searching. To the question, "who governs suburbia?," or even "who speaks for suburbia?," there is still no answer.

The political party is not only the vehicle for providing professionals to man vital civic and governmental posts. More importantly it also can be the means for shaping and channeling public opinion and making the public debate on issues and programs sharper. The virtues both of responsiveness and responsibility can be gained. The formlessness of a civic association and a federation of civic associations is inadequate to the task of providing continuous surveillance in communities of hundreds of thousands of people spread over masses of territory part of which is balkanized into towns and subcities, and part of which is unorganized and is relying on the county, the special tax district, and service contracts.

II

\section{Needed: A Metropolitan Constitution}

The problem of constitutionalizing suburbia and of integrating it with the core city is in part a political party problem, because the need is not to further incorporate

775 (1964); O. P. Williams \& Chas. R. Adrian, Four Cities (1963); Edward C. Banfield \& J. O. Winson, City Politics (1963). 
and further balkanize suburbia but to develop suburban-wide and metropolitanarea-wide political outlook, with appropriate political leaders and political organization. Political leaders, of course, must be tied to some elective posts. We have learned from the international field the impossibility of creating international law and politics without an international government.

However, as in the international field by analogy, it has proven to be easier to suggest the creation of metropolitan-area-wide (metro) elective positions than to accomplish the feat in fact. Metropolitan area government in the form of a citycounty consolidation, or a city-county federal division of functions, or a superimposed "metro" government to handle designated functions, has had little appeal when sub. mitted to popular referenda. The victories in Dade County (Miami) Florida, and Nashville and Knoxville in Tennessee are offset by a string of defeats in St. Louis, Cleveland, Seattle (a reduced one-function agency was later approved), and elsewhere. ${ }^{8}$

The "metro" concept, however, apart from some of the forms by which it is sought to be advanced, is basically sound. It is simply one more manifestation of the age-old trend toward "centralization of power," defined as the transfer of effective power of political decision to higher governmental levels encompassing wider geographic area. ${ }^{9}$ Centralization of power, thus defined as a descriptive rather than a pejorative term, has innumerable examples in world history going at least as far back as the shift from the Greek city-state to the amalgam that was Rome. Rome was viable, the Greek city-state was not. Similarly in the metropolitan area, the village and township, and a fortiori the unorganized subdivision, show little viability. Even when centralized units have broken up, as in the disintegration of the Roman Empire into decentralized quarreling feudalism, a recentralization of power in turn was prerequisite to successful emergence from feudalism. Examples could be multiplied, but the lesson that emerges is that centralization of power seems to be a price of efficient utilization of resources and technology.

Opponents of "metro" developments and other attempts to constitutionalize our urbanization are often moved by fears of losing "democracy" and "freedom." These values, however, do not have a primary relationship to centralization of power, which is really only a concept of power in relation to area. ${ }^{10}$ Democracy and free-

${ }^{8}$ See Scott A. Greer, Metropolitics (1963); U.S. Advisory CoMmission on Intergovetinmental Rezations, Factors Affecting Voter Reactions to Governmental Reorganization in Metropolitan Areas (I962); Edward Sofen, The Miami Metropolitan Experiment (1963).

- The centralization theme and its relation to technology is developed further in Dixon, Constitutional Bases for Regionalism: Centralization; Interstate Compacts; Federal Regional Taxation, 33 Gro. WasH. L. Rev. 47 (1964), from which some of the remarks in this section are adapted. Sec also Gronoz C. S. Benson, New Centrazization: A Study of Intergovernmental Relationships in the United States (I94I).

${ }_{10}$ Provocative essays on "areal division of power" and its relation to the base values of liberty, equality and welfare are contained in Arthur Masss (Ed.), Area and Power: A Theory of Local Government (1959).

See also two reports of the U.S. Advisory Commission on Intergovernmental Relations: PenformancB of Urban Functions: Local and Areawide (1963); Alternative Approsches to Governmental Reorganization in Metropolitan Areas (rg62). 
dom relate primarily to the degree of concentration of power, and the manner of legitimization of power, within the system, whether it be centralized or decentralized. Power can be "legitimized" by force alone or by a free election system, and in the latter many choices are open in regard to frequency of elections, staggering of terms, and so forth. And power can be "concentrated" in an executive head, or in a legislature, or be shared in various fashions between the two.

At bottom "centralization" is no more than an attempt rationally to relate governmental forms and institutions to the geographic breadth of the public need for uniform regulations and minimum service standards. The problem in the Ig6os and I970s is to find a unified and constitutionalized governmental home for metropolitan man. A similar problem on a national scale existed in 1787 and the answer was the centralization of power document known as the United States Constitution. And just as the responsiveness of corporate management is not causally related (at least directly) to the degree of geographic spread or intercorporate connections of the corporation, so the responsiveness of government is not causally related to the kind of areal division of power which prevails at any given time. A centralized government-a metro-can be a responsible and responsive government. And a decentralized government with authority for various functions distributed among town, city, and county-and with some large vacuums-can yield irresponsibility as well as diffusion of power.

\section{III}

\section{Alternative Approaches}

There has been no dearth of writing on metropolitan area problems and of suggested solutions. Indeed, whole bibliographies are devoted to keeping up with the flow. ${ }^{11}$ For the limited purpose of the present essay it is important only to note the

${ }^{11}$ See, e.g., the continuing bibliographies included as part of Metropolitan Area Problems, News and Digest; the Government Affairs Institute bibliography; the bibliographies published by the Senate and House Subcommittees on Intergovernmental Relations of the Committees on Government Operations; the notes and bibliographies published regularly in the National Civic Review.

Sec Otis Duncan and Others, Metropolis and Region (I960); Luther H. Gulick, The Metropolitan Problem and American Ideas I-27 (1962); Harvey S. Perloff and Others, Regions, Resources, ANd Economic Growth (I960); Robert M. Fisher (Ed.), The Metropolis in Modern Iife (I955); Studenski, Metropolitan Areas 1960, 49 Nat. Crv. Rev. 467, 537 (I960).

See also Ely, Intergovernmental Cooperation Trends, Loc. Gov'T L. SERv. LETTER, Vol. I4, No. 5 (May I964); Beckman, Alternative Approaches for Metropolitan Reorganization, 92 Public MaNagement 55 (I964); Jolnt Center for URban Studies, MIT and Harvard Univ., The Effectiveness of Metropolitan Planning, for Senate Comm. on Government Operations, 88th Cong., 2D Sess. (Comm. Print. Ig64); U.S. Housing and Home Finance Agency, National Survey of Metropolitan Planning, for Senate Subcomm. on Intergovernmental Relations, 88th Cong., ist Sess. (Comm. Print 1963); Joint Hearings on Government in Metropolitan Areas Before Subcommittee on Intergovernmental Relations of the Senate and House Committees on Government Operations, 88th Cong., Ist Sess. (1963); Hearings on the Role of the Federal Government in Metropolitan Areas Before Senate Subcommittee on Intergovernmental Relations of the Senate Committee on Government Operations, 87th Cong., 2d Sess. (1962); U.S. Advisory Commission on Intergovernmental Relations, Governmental Structure, Organization, and Planning in Metropolitan Areas, House Comm. on Government Operations, 87th Cong., ist Sess. (Comm. Print I96I); State University of New York, Graduate School of Public Affairs, Metropolitan Area Problems: News and Digest (periodic). 
variety of possible approaches. A recent study published by the Housing and Home Finance Agency (HHFA) lists eight devices for "procedural adaptation," ranked by degree of impact as follows: ${ }^{12}$

I. Informal cooperation, e.g., the sharing of police teletype, intelligence, or equipment.

2. The service contract for such things as water and sewage disposal, which in Los Angeles County has been carried to the point where a city may make a "package deal" with the county for all municipal services.

3. Parallel action, i.e., the authorization by "joint powers" legislation for local governments to enter into agreements for joint performance of any function which the cooperating governments have the power to undertake individually.

4. The conference approach, i.e., a metropolitan regional council of governments composed of elected officials from the local governments within the metropolitan region, meeting regularly to work out patterns of cooperation, standard ordinances, and so forth.

5. The compact, i.e., a formalization of No. I above, such as the agreement between two counties in Kentucky to form the Northern Kentucky Area Planning Commission. Major problems across state lines can be handled only by interstate compact, but inter-local agreements to formalize cooperative action on lesser problems have been authorized in New York, Connecticut, and New Jersey.

6. Transfer of functions, usually on a limited ad hoc basis, such as transfer to the county of responsibility for suburban water problems.

7. Extraterritorial jurisdiction, i.e., state authorization for cities to establish facilities outside their limits for water supply, sewage, recreation.

8. Incorporation, i.e., the creation of a new municipality.

${ }^{12}$ U.S. Housing and Home Finance Agency (Martin), Metropolis in Transition 5-8 (1963). This work also includes a selected topical bibliography, confined largely to governmental or political science sources. See the following reports of U.S. Advisory Commission on Intergovernmental Relations: Alternative Approsches to Governmental Reorganization in Metropolitan areas (1962); Governmental Structure, Organization, and Planning in Metropolitan Areas (i961); Sugcested Action by Local, State, and National Governments (196r); State Constrtutional and Statutonx Restrictions upon the Structural, Functional, and Personnel Powers op Local Government (1962); The Problem of Special Districts in American Government (1964); and reports cited in notes 8 and ro supra.

See the following titles in Universtiy of Michigan Law School Series, Legal Problems in Metropolitan Areas: Frank S. Sengstock, Annexation: A Solution to the Metropolitan Area Prodlem (1960); John M. Winters, State Constitutional Limitations on Solutions of Metropolitan Area Promlems (ig61); Neil Littlefield, Metropolitan Area Problems and Municipal Home Rule (ig62); Max A. Pock, Independent Special Districts: A Solution to the Metropolitan Area Problem (I962); Frank S. Sencstock, Extraterritorial Powers in the Metropolitan Area (1962); John M. Winters, The Interstate Metropolitan Area (ig62); Larry M. Elison, The Finances of Metropolitan Aress (1964).

See also Winston W. Crouch \& Beatrice Dinerman, Southern California Metropolis: A Study in Developdent of Government for a Metropolitan Area (xg63); Owsley, Kentucky Interlocal Cooperation Act, 5I Kx. L. J. 22 (I962); Frank S. Sengstock and Others, Consolidation: Building a Bridge Between City and Suburb (1964); Donoghue, County Government and Urban Growth, I959 Wis. L. Rev. 30; Grubbs, Legal Aspects of City-County Consolidation in Tennessee, 30 TENN. L. Rev. 499 (1963); N.Y. State Office for Local. Government, Local Government Cooperation (I963). 
The HHFA study also goes on to list eight devices for "structural adaptation," ranked by degree of impact as follows: $:^{13}$

I. Annexation, i.e., the extension of the city boundary to include unincorporated fringe areas.

2. City-county separation, i.e., the reconstitution of a major city as a separated citycounty. Prior to 1902 Baltimore, Denver, St. Louis, and San Francisco received this treatment. Today the practice exists only as an oddity in Virginia, where the separation practice is a constant threat to the continued viability of the counties.

3. Geographical consolidation, i.e., the relatively infrequent practice of city-city consolidation, city-county consolidation, etc. After the nineteenth century consolidations involving Boston, Philadelphia, New Orleans, and New York, there was a a long lull. A recent major consolidation involves Nashville and Davidson County, Tennessee.

4. Functional consolidation. Although classified separately in the HHFA study this seems to be merely a "structural" way of looking at some "procedural" adaptations already listed above, e.g., parallel or joint action, a compact, transfer of functions.

5. The special district, i.e., the creation of single-purpose or multi-purpose districts for schools, water, sewage, etc. Special districts normally have taxing power but not power to issue revenue bonds.

6. The authority, i.e., the creation of a public agency in the fields of housing, mass transit, etc. The "authority" normally differs from the "special district" in lacking a tax power and possessing instead a power to issue revenue bonds, defrayed by user charges.

7. Metropolitan government, i.e., the creation through consolidation, massive transfer of functions to the county, or special charter of a general purpose governmental unit with jurisdiction throughout the metropolitan area.

8. The regional agency, i.e., the creation of a special purpose supra-metropolitan agency to handle problems such as water supply and transportation which extend beyond a single metropolitan area. Most examples involve interstate compacts, e.g., the recently created Delaware River Basin Commission.

A similar list is contained in a Ig62 study by the United States Advisory Commission on Intergovernmental Relations, but with fewer overlapping headings so that ten alternatives emerge: ${ }^{14}$

x. Use of extraterritorial powers.

2. Intergovernmental agreements.

3. Voluntary "metropolitan councils."

4. The urban county.

${ }^{13}$ U.S. Housing and HoMre Finance (Martin), op. cit. supra note iz.

14 See Alternative Approaches to Governmental Reorganization in Metropolitan Areas, op. cit. supra note 10, at ch. IV. 
5. Transfer of functions to the state government. (This is a heading not included in the HHFA list.)

6. Metropolitan special districts: limited purpose and multipurpose.

7. Annexation and consolidation.

8. City-county separation.

9. City-county consolidation.

ro. Federation (borough plan), i.e., a species of local "federalism" with some func-. tions continued in local units and some vested in a metropolitan-area-wide agency. In an unplanned way, such a federal or borough arrangement already may exist in most states which have city, village, or township units operating within counties.

Few of these devices are mutually exclusive, and many are supportive of each other. Many of them, however, are not devices, or even important stepping-stones, toward true metropolitan government, e.g., extraterritorial jurisdiction of cities, service contracts, special districts, public authorities. They do not envision a broad metropolitan-area-wide government in which metropolitan man can become a metropolitan citizen and acquire a direct voter relationship between himself and a set of officials performing at least a goodly number of metropolitan functions.

\section{IV}

\section{The Problem of Boundaries}

Central to any discussion of re-constituting our urban areas is the problem of boundaries. The lines, which also denote important jurisdictional allocations, can be created by incorporation of municipalities or special districts, can be extended by annexation or consolidation, and can be ignored or surmounted by such devices as extraterritorial powers and service contracts.

In all cases of establishment of boundaries the central problem, and the most unprovided for problem, is the general lack of any power of review of the basic determination of whether or not to establish the boundary. Under incorporation ${ }^{16}$ and annexation ${ }^{16}$ statutes, courts of course do review to ensure that various formalities have been met. But the basic political decision to establish the boundary-and it is a political decision, and therefore not properly delegable to a court ${ }^{17}$-normally is

${ }^{25}$ Mandelker, Municipal Incorporation on the Urban Fringe: Procedures for Determination and Review, 18 LA. L. REv. 628 (r958); Mandelker, Standards for Municipal Incorporations on the Urban Fringe, 36 Texas L. Rev, 27 r (1958).

${ }^{16}$ Frank S. Sengstock, annexation: A Solution to the Metropolitan Area Problem (1960); Robert G. Dixon, Jr. \& John R. Kerstetter, Adjusting Municipal Boundaries: The Law \& Practice in 48 States (I959). See also Note, Stumbling Giants-A Path to Progress Through Metropolitan Annexation, 32 Notre DaMe Law. 56 (1963).

17 This is certainly the dominant view in the states. For individual states see comments in DixoN \& KERSTETTER, op. cit. supra note 16, as follows: Ark. 54; Idaho 96; Ill. 102; Ind. I14; Kan. I26; Ky. 134; La. I43; Mich. 159; Minn. I75; Miss. I82; Mo. 186; Mont. 193; Nebr. 197; Nev. 205; N.Y. 219; N.C. 226; Okla. 242; Ore. 248; Pa. 258; S.C. 27I; S.D. 276; Tenn. 28I; Tex. 29r; Utah 299; Va. 307; W. Va. 326; Wyo. 339 .

In regard to federal review, the "political question" doctrine has been applied and it has been held 
left in the hands of the immediately interested parties. As a result a city may be hemmed in, and find annexation pathways blocked, by defensive incorporations on the urban fringe. Uneconomic units may be created for lack of adequate information. At the very least an unplanned, spasmodically created, checkerboard of overlapping local units and districts results. Many of our traditional arrangements, unfortunately, put a premium on pettiness and parochialism.

Recently some restraints have been applied to the casual process of creating and changing local boundaries. Some annexation-incorporation statutes have been amended to impose additional standards, e.g., to forbid, without consent of the city, an incorporation within a designated number of miles from the existing city boundary. ${ }^{18}$ More grandiose are the provisions for local boundary commissions. Examples include Minnesota, ${ }^{19}$ Alaska, ${ }^{20}$ and California. ${ }^{21}$ The purpose of such com-

that incorporations-annexations do not present justiciable federal questions. Hunter v. Pittsburgh, 207 U.S. 16I (1907); Clark v. Kansas City, I76 U.S. II4 (x900); Kelly v. Pittsburgh, ro4 U.S. 78 (I88I); Mount Pleasant v. Beckwith, Ioo U.S. 514 (1879); Commissioners of Laramie County v. Commissioners of Albany County, 92 U.S. 307 (I875); Clay v. Eustis, 7 F.2d I4I (S.D. Fla. 1925), appeal dismissed, 273 U.S. $78 \mathrm{I}$ (1926); Forsyth v. Hammond, I66 U.S. 506 (I897) (semble). A recent dismissal for want of a federal question seems to reinforce this federal line of authority. Texas ex rel. Pan American Production Co. v. Texas City, 157 Tex. 450, 303 S.W.2d 780 (1957), appeal dismissed, 355 U.S. 603 (r958).

However, there is a line of cases which may seem to be inconsistent with the Hunter line of precedent, suggesting that abuse of power in special district annexations would present a reviewable federal question. See Houck v. Little River District, 239 U.S. 254 (1915), Myles Salt Co. v. Iberia Drainage District, 239 U.S. 478 (1916), and discussion in Comment, Per Curiam Decisions of the Supreme Court: r957 Term, 26 U. CHI. L. REv. 279, 315-I7 (r959). A distinction which could be suggested is that a review merely for the purpose of enforcing some due process "grundnorms" of fairness is not inconsistent with a rule of non-reviewability of the basic decision to incorporate or annex. The due process grundnorms merely would indicate the price of going forward with the political decision.

${ }^{18}$ E.g., IOWA COde ch. 362.I (1962); OKLA. Stat. ANN. ch. II-97II, II-55I (I96I); TENN. COde ANN. ch. 6-105, 6-1803 (Supp. 1964). For discussion of this and related matters, see Dixon \& KerSTETTER, op. cit. stipra note 16 , at $115,122,244,283$, and index references generally on individual state provisions regarding standards of annexability, special districts, revisions proposed or enacted, etc.

See also Beckman \& Brazer, Governments Galore: Let's Eliminate Incentives for Creating Specific Districts and Restrict Authority to Incorporate, 52 NAT. Crv. Rev. 132 (1963); Note, New Control over Municipal Formation and Annexation, 4 Santa Clara L. Rev. 125 (1963).

${ }^{10}$ Minn. Stat. Ann. $\$ \$ 414.01-414.07$ (Supp. I964). Minnesota is the leading example of this development. For recent comments by Joseph Robbie, Chairman of the Minnesota Municipal Commission, see Robbie, A State Municipal Boundary Commission Meeting the Need for Administrative Review of Proposed Incorporations and Annexations Through Impartial State Agency, 37 Mich. Munic. Rev. 7 (1964); Robbie, Municipal Annexation, as part of report of Committee on Individual Rights of ABA Section on Local Government Law, Loc. Gov't L. SERv. LeTTER 26 (December I964, Committee Reports Supplement). The Commission will have available shortly a report to the legislature covering its first five years of existence.

A 1963 amendment to the Commission's statute allows the people in the affected territory to vote on annexations approved by the Municipal Commission, thus leaving the Commission with a veto power but no power to compel annexation against the wishes of the proposed annexees.

${ }^{20}$ Alaska Const. art. X, $\$ 2$; Alaska Stats. $\$ \$ 44.19 .250-44 \cdot 19 \cdot 340$ (I962).

${ }^{21}$ CaL. Gov't Code $\$ 54775-9 \mathrm{I}$. The new Local Agency Formation Commission law has been summarized as follows by Robert L. Small, Executive Officer of the San Diego Local Agency Formation Commission: "The formation commissions were established as a result of 1963 legislation. There are 57 of them in the state of California and they are made up of local officials within each county. The five members of the commission represent the county government in the person of two county officials, normally supervisors; city government in the person of two mayors selected by all of the mayors in the county; and the fifth public member selected by the other four members. The formation commissions have the power and responsibility for the review of city incorporation, district formation, and city and 
missions is to provide some mechanism for disinterested review, at a level above the disputing parties, of the factual basis and competing policy considerations which enter into the creation or modification of local boundaries. The basic theme in Alaska and Minnesota seems to be that urban and metropolitan restructuring is a matter of state-wide interest and concern, and must be developed from the perspective of the entire state. In California the new intra-county Local Agency Formation Commissions do provide some regional focus and may serve to make local planning much more realistic. ${ }^{22}$ In other words, home rule is not appropriate until higher authorities establish the boundaries of the home and resolve jurisdictional contests between homes.

Although no "right" path to change may exist, the mere existence of such commissions puts on the proponent and opponent of boundary change the onus of thinking deeply about it, and coming up with some reasoned arguments. As all investigatory bodies know, much may result from the mere power to ask the little question -why?

With the details of this development we are not now concerned. Annexation, however, is relevant to the "constitutionalizing of metropolis" theme of this essay. Classified in terms of power of approval of annexation, the modes of annexation authorized by state law fall roughly into six major categories, and of course some states lack one or more of the categories. The modes are ${ }^{23}$ (I) bilateral annexation, i.e., after consent of both fringe and city has been expressed by some combination of petition and election, or petition and ordinance procedures; (2) unilateral annexation by the city, i.e., full power in the city to accomplish annexation by the device usually of ordinance or charter amendment; (3) unilateral annexation by the city subject to judicial remonstrance, i.e., opportunity for the fringe to appeal to court before annexation becomes final; (4) annexation by court order after initiation either in the city or in the fringe area; (5) annexation by approval of outside body other than a court; (6) annexation by special act of the state legislature.

For the present purposes the important ones are those under which annexation may occur without the consent of those being annexed, i.e., unilateral annexation or annexation by judicial order. The latter, judicial annexation, involves a monstrous violation of the separation of powers tradition of confining courts to "non-political" activity. ${ }^{24}$ There is no "right" to be adjudicated in an annexation case regarding

district annexation proposals prior to circulation of petitions or action by the appropriate local governing board. The commission does not have jurisdiction over withdrawals of territory from districts or cities or over the consolidation or dissolution of special districts. The commissions have the power to approve, disapprove, or approve with modifications or conditions any proposal that comes before them. If a proposal is disapproved, no proposal involving substantially the same territory may be made for one year after the commission's original action." Statement of Panel Presentation, National Municipal League meeting, San Francisco, Nov. 20, 1964, p. I (mimeo.).

${ }_{22}$ As Mr. Small phrased it, id. at 2: "[P]lanning as we have known it, has not given adequate consideration to ultimate or anticipated local governmental jurisdictions."

${ }^{2 s}$ Adapted from Dixon \& Kerstetrer, op. cit. supra note $\mathrm{x} 6$, and my talk, "Annexation Techniques and the Judicial Role," before ABA Municipal Law Section, Washington, 1960.

${ }^{24}$ Although the dominant view is that annexation by judicial order is both unwise and unconstitutional, 
the basic question of whether or not to annex. It is a decision to be made in terms of the vision of urban development which prevails in a given area at a given time. It is a straight policy decision.

Virginia's basic annexation statute is an extreme and well-known example of annexation by judicial order. It has been aptly referred to as Virginia's "not so judicial"25 method. A striking feature of the system is the breadth of discretion of the annexation court. ${ }^{26}$ It is to determine the "necessity for and expediency of" annexation in the light of such considerations as the "best interests" of county, city or town, and territory; adaptability to city improvements; and the city's needs for future development. The discretion of the annexation court in Virginia is enhanced by two additional factors. The judges themselves are empowered to alter the boundaries as proposed by the initiating party. They also may set forth in the annexation order such terms as to them seem "fair and reasonable." Virginia's virtual blank check delegation of annexation power to the courts-like the broad judicial remonstrance system of Kentucky and Indiana ${ }^{27}$ - would not pass muster in many courts. The Virginia Court of Appeals came near to the heart of the matter when it observed that the doctrine of separation of powers, and its corollary principle of prohibiting conferment on the courts of non-judicial functions, has seldom been vigorously applied in Virginia. ${ }^{28}$

Judicial annexation, especially if it is of the broad type practiced in Virginia, is not even relieved by the "egalitarian" thesis that lends some color of objectivity to the recent wave of legislative reapportionment cases. Nor is it relieved by any "necessity" argument which is the true rationale for Baker v. Carr. ${ }^{29}$ For annexation, other alternatives than the courts are available.

Unilateral annexation, by contrast, puts controlling power in the hands of the city, limited to an extent perhaps where there is a boundary commission with supervening or review authority. Several states authorize a summary procedure of annexation for specified types of tracts which are relatively innocuous politically, such as city-owned territory. For years Texas $^{30}$ has been the dominant example of

supra note I7, the practice occurs in a number of states either in direct form (e.g., Virginia) or in limited form as part of a remonstrance procedure (e.g., Indiana, Kentucky, North Carolina, Missouri, and Tennessee). For cases see Forsythe v. City of Hammond, I42 Ind. 505, 4I N.E. 950 (1895); Kraft v. City of Louisville, 297 S.W.2d 39 (Ky. I956); Witt v. McCanless, 200 Tenn. 360, 292 S.W.2d 392 (1956); City of St. Joseph v. Hankinson, $3 \mathrm{r}_{2}$ S.W.2d 4 (Mo. 1958). For Virginia, see text accompanying note 25 infra.

${ }_{26}$ Bain, Annexation: Virginia's Not-So-Judicial System, 15 Pub. Admm. Rev. 25I (I955). See also Virginia Annexation Laws Reviewed, 53 Nar. Crv. Rev. 267 ( 1964$)$.

${ }_{30}$ The leading case is Henrico County v. City of Richmond, I06 Va. 282, 55 S.E. 683 (1906).

${ }^{27}$ See citations supra note 18 .

${ }^{28}$ Henrico County v. City of Richmond, supra note 26.

${ }^{20}{ }_{3} 69$ U.S. $186(1962)$. Elsewhere I have suggested that in holding in 1962 that legislative apportionment raised justiciable issues the Court could have used a "necessity-changing times" principle analogous to the rationale used in Brown v. Board of Education, 347 U.S. 483 (1954). See Dixon, Legislative Apportionment and the Federal Constitution, 27 LAw \& Contemp. Pros. 328, 354 (1962).

${ }^{30}$ See City of Houston v. State ex rel. City of West University Place, $\mathrm{r}_{42}$ Tex. I90, I76 S.W.2d 928 (1943); Allen v. City of Austin, Ir6 S.W.2d ${ }_{4} 68$ (Texas Civ, App. 1938). 
a broad power of unilateral annexation of all types of adjacent unincorporated territory, and in a few other states certain classes of cities have a similar broad power. ${ }^{31}$ The difficulty with unilateral annexation is two-fold. First, it puts in a part of the metropolitan area the power of determining the nature of the development of the entire area. Secondly and more importantly, given the predictable continuance of the process of urbanization, there is no natural stopping point to the process of unilateral annexation as Texas experience indicates short of the county line-or the line of defensive incorporation in the urban fringe. Except for the latter factor of defensive or pre-emptive incorporation, unilateral annexation envisions cities becoming coterminous with counties.

As a stepping stone to city-county consolidation in the present minority of states where unilateral annexation is authorized, there may be some virtue in this development. Even in these states, however, the story of past "metro" efforts suggests that strong opposition may exist to submergence of the county. For the majority of states, where cities lack unilateral annexation power or already are circled by a choker necklace of incorporated territory, the annexation route to constitutionalizing the metropolitan area by building on the base of the central city is impossible.

It would appear then that annexation is a device of limited utility in most states as a basis for constitutionalizing the metropolitan area. In the minority of states where it exists as an instrument for vigorous city expansion it logically runs to the county line. And it thus raises the basic policy question whether the central city or the county should be the basic building block for the escalation we soon will face from large metropolis to sprawling metropolitan regionalism.

\section{V}

\section{Two Solutions}

In the perspective of the next twenty-five years the question really is not whether, but how, metropolitan governmental arrangements within metropolitan areas will be achieved. It is a political problem, a constitutional problem, and very immediately a human relations and citizen acceptance problem. As noted, most ambitious "metro" plans have failed to receive voter approval. At least two less ambitious approaches hold much promise.

Council of Governments Approach. One approach is to build on the existing elective officials and the existing political party structure, through establishment of area-wide councils of governments, thus linking the area legislators and political leaders. Approximately eight examples already exist, including the Association of Bay Area Governments (San Francisco region) and the Metropolitan Washington Council of Governments (National Capitol region). ${ }^{32}$ The latter, and the Mid-

\footnotetext{
${ }^{81}$ Examples include Missouri, Nebraska, and to a lesser extent, Kansas and Idaho. Sec generally DiXON \& KERSTETTER, op. cit. supra note I6.

${ }^{32}$ Others, well established by 1962 , included the Supervisors Inter-County Committce (Detroit area);
} 
Willamette Valley Intergovernmental Cooperation Council, have been subjected to fairly extensive analysis. ${ }^{\mathbf{3}}$

It is important that these councils be based on the area legislative bodies so that they will be part of the existing power structure. They should not be mere leagues or associations of planners. Of the latter there are many examples, but they seem to solve few problems other than provision of employment for more planners, to plan the integration of plans previously made. ${ }^{34}$ On a local politician-legislator base the council plans may be less grandiose but the accomplishments will be more enduring. Planning is a necessary adjunct to politics; but the political base may be established first.

An example is the Year 2000 Plan for the National Capital Region, which was completed in 196r and ordered into use by President Kennedy a year later as a guide for federal agency land-use policies. By Ig63, however, it was reasonably clear that no suburban planning agency, with one possible exception, seriously intended to use the document as a policy guideline..$^{35}$

Whether the council is confined to one county, or transcends county lines as in the case of some existing councils, is a particularized local issue and does not affect the utility of the council device.

The statements made four or five years ago about the benefits to be derived from the council of governments movement may have been overly optimistic. ${ }^{36}$ Three more recent studies are more reserved. For example it has been pointed out: (I) that the council's strength in being a body of locally elected politicians is also a weakness because the council's most effective members may be defeated in local elections

Metropolitan Regional Council (New York, New Jersey, Connecticut); Mid-Willamette Valley Intergovernmental Cooperation Council (Salem, Oregon area); Regional Conference of Elected Officials (Philadelphia area); the Puget Sound Governmental Conference (Seattle-Tacoma area); the Baltimore Metropolitan Area Council. See summary and evaluation in U.S. ADvisory CoMmission on INTERgovernMENTAL Relations, Alternative Approsches to Governmental Reorganization in Metropolitan Areas, op. cit. supra note Io, at 34-38.

Private metropolitan affairs nonprofit corporations, such as the Detroit area Metropolitan Fund, Inc., may play a supportive role, as discussed in Mathewson, Broader Horizons, 54 Nat. Civ. Rev. 136 (1965).

${ }^{33}$ U.S. Housing and Home Finance Agency (Martin), op. cit. supra note 12, at 27-50; Washington Center for Metropolitan Studies (Hanson), The Politics of Metropolitan Cooperation: MetroPOLITAN Washington Councli OF GOVERMMENTS (I964).

${ }^{34}$ At a conference at the Brookings Institution which this writer attended a few years ago the dean of a school of architecture and planning brought the house down with his remark that the career story of many city planners was to go from failure to failure right up the ladder of success.

sE WAshangton CENTER fOR MEtropolitan Studies (Hanson), op. cit. supra note 33, at 68 . This study faults the Metropolitan Washington Council of Governments for not acting on the Year 2000 Plan for two years, by which time non-use of the Plan by the area local governments was becoming clear. Perhaps the more meaningful observation is that plans prepared outside the political process and presented to political leaders for ratification will have a cool reception, and that the role of a council of governments is to participate in, or direct, the planning process and not to serve merely as a broker. Such participation is suggested in this study.

${ }^{36}$ See Jones, Cooperation Pattern, $5 \mathrm{r}$ NAT. Crv. Rev. 302 (x962); Leach, New Urban Challenge, 50 Nat. Crv. Rev. 480 ( $(96 \mathrm{r}$ ). For a review of accomplishments see Humes, Washington Area Reports Progress, 50 Nat. Crv. Rvv. 550 (I96r). Also see Parker, Cooperation in Metropolitan Areas Through Councils of Government, 65 Pub. Managemenr 223 (1963); Schrader, Voluntary Metropolitan Government Councils, american Society of Planning Officials, Information Report No. i6i (1962). 
on non-council-related issues; ${ }^{37}$ (2) that the rule of unanimity magnifies the veto power of local interests; ${ }^{38}$ (3) that the councils so far operate well only in regard to noncontroversial problems which can be solved with little cost through decisions which will be largely self-executing. ${ }^{39}$

However, the council of governments concept is basically sound. Merely by existing a council of governments is an achievement of sorts. Unlike planning, which is mainly a question of money, the creation and operation of a council of governments is an exercise in human relations-political relations-with many of the problems of a United Nations on a local scale. Councils have accomplished some things in their own right, and they have a major role as a bridge device toward more simplified and direct forms of political and legal organization for metropolitan areas. A decade hence much that now seems impossible may be accomplished and appear in retrospect as the obvious path dictated by human need and political wisdom.

The Reapportioned County. The other approach which seems to merit major emphasis is to center attention on the county as the chosen instrument for metropolitan salvation. In some areas a form which can be called the "urban county" already is emerging. Even in those areas where a metropolitan region spreads across more than one county, the county is the largest available building block and it has the prime virtue of already being in existence. As noted in one recent study:40

In some 135 of the 212 SMSAs of rg6r [Standard Metropolitan Statistical Areas of the Bureau of the Census], however, the metropolitan area lay wholly within the confines of a single county. Not every county constituting an SMSA is a potential metropolitan government, but many are. Where the major city lies near the center of the county, where there is elbow-room for suburban growth, where the county has manifested an awareness of urban growth and an interest in urban problems, where the county has shown a disposition to municipalize its services-in such a situation the county may be the logical repository for metropolitan responsibilities.

Of course, there are major obstacles to this development. For years perhaps the most crucial one-because it has blocked other developments- has been the malapportionment of county boards. As noted in a 1962 report: "A deterrent to transferring more power to counties in some States is the existence of inequitable representation in the governing body, often with the central city and the suburbs on opposite sides of the issue." 41

37 WAShnoton CENTER fOR METropolitan Studies (Hanson), op. cit. supra note 33, at $7 \mathrm{I}$.

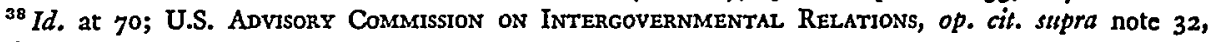
at 38 .

so U.S. Housing and Home Finance Agency, op. cit. supra note 12, at 48-49.

${ }^{\circ}$ U.S. Housing and Home Finance Agency (Martin), op. cit. supra note 12, at 89. Sec also Note, Urban County: A Study of New Approaches to Local Government in Metropolitan Areas, 73 Hanv. L. Rev. 526 (1960); Grossman, Counties Come to Life, 53 NAT. Crv. Rev. 429 (1964), suggesting that a newly developed partnership with municipalities is putting counties in a position of leadership.

${ }^{1}$ U.S. Advisory Commission on Intergovernmentar Relations, op. cit. supra note 32, at 45 , and see generally the urban county discussion, $i d$. at $38-46$ and references cited therein. 
The primary justification for suggesting at this time that the county be viewed as a potential, ready-made "metro" unit, lies in recent activities of the United States Supreme Court and their potential revolutionary impact on the form and quality of county government and on popular respect for county government. The wave of legislative reapportionment suits, which are re-making the political map of America in the wake of Baker $v$. Carr, ${ }^{42}$ already have reached the county board level. Baker, in 1962 , authorized judicial entry into the political thicket of state legislative reapportionment. The culmination of Baker was the Supreme Court ruling in the Reapportionment Decisions of June ${ }_{5}, \mathrm{I}_{964},{ }^{43}$ that both houses of a bicameral state legislature must be elected from districts of substantially equal population.

Within three months this new equal population districts principle-dubbed "one man-one vote" by many-was applied to the county board of supervisors by the circuit court for Kent County, Michigan, in Brouwer v. Bronkema. ${ }^{44}$ On the Kent County Board of seventy-three supervisors, drawn from twenty-two townships and eight cities, per capita representation ranged from a low of one supervisor for 925 people to a high of one supervisor for 15,000 people. As a rare instance a wide range between the one largest and the one smallest district may be supportable to provide some representation to a small, unique, isolated unit. But the average deviation, which is the more meaningful statistic, was also extreme in Kent County. For only seven supervisors did the population per capita representation ratio vary by less than 2,000 from the ideal ratio of 5 100. In other words, with a mean of 5 roo, the representation ratio for all but six supervisors fell outside a range of 3I00 to 7roo.

Because the fourteenth amendment, which is the basis for the Reapportionment Decisions, applies equally to local and state governments, it is logical that whatever individual right is found to exist vis-à-vis the state legislature should exist also in regard to the local legislature. The path to this conclusion is eased by the Supreme Court's failure to characterize the right at issue as being one of representation. In the meaningful, functional sense such characterization would require consideration of interest and party alignments and the many inequities, riggings, and minority submergence factors which can operate to defeat fair representation, even with equal population districts. Instead the Court in the Reapportionment Decisions approached the matter wholly abstractly as an individual right to something called an "equally weighted vote," and then indulged in the convenient non sequitur that the right could be achieved by taking bare census data and arranging it in equal piles, i.e., districts. $^{45}$

\footnotetext{
12369 U.S. I86 (1962).

${ }^{3}$ See Reynolds v. Sims, 377 U.S. 533 ( $(964)$, from Alabama, and the companion cases from New York, Maryland, Virginia, Delaware, and Colorado.

“Opinion and decision fled Sept. II, I964. Unfortunately, this landmark case with a perceptive opinion is unreported. References hereafter are to photocopy of manuscript opinion.

4T The difficulty with the Court's formulation is that it is an incomplete and overly literal application of the equal protection clause, not that it is wholly wrong. Population should play a dominane role in apportionment and districting. The facts of most of the cases decided so far show extreme divergences
} 
Accordingly, in the Kent County case Judge Searl had little difficulty in finding for the plaintiff, as follows: : $^{\mathrm{e}}$

It is the "supreme law of the land" that each "person" have equal representation in the legislative body in which the legislative power of the State is exercised and such right requires that the membership of such body be apportioned on a population basis. A part of the legislative power of the State is delegated to and exercised by County Boards of Supervisors. That Board, like its parent body, the State Legislature, must be apportioned on a population basis if all persons in the County are to have equal representation therein.

He also said, in the specific context of the Michigan case, that it is "not material that the State, in delegating legislative powers to the Board of Supervisors, has provided that the members of the Board may be in part appointed and not elected at the polls." ${ }^{\text {* }}$

Since this ground-breaking decision similar rulings, invalidating malapportioned county boards, were made early in 1965 by the Wisconsin Supreme Court in State ex rel. Sonneborn v. Sylvester ${ }^{48}$ and by a federal district court in New York in Bianchi v. Griffing. ${ }^{49}$

It seems clear that within a very few years most county boards in the nation, unless elected at large, will be reapportioned on something approaching a straight population basis. In the majority of states outside the South county boards traditionally have been elected from districts of unequal population, rather than at-large. Even those states with a tradition of at-large election of county boards may feel the impact of the reapportionment rulings-in two ways.

First, the practice of requiring that the board members, although elected at large, reside for nomination purposes in districts of unequal population, is certain to be challenged. The practice may very well be voided on the ground that the

from the arithmetic mean of per capita representation, obtained by dividing the total population by the number of representatives. However, in rectifying this situation it is not at all clear, from the standpoint of "democratic rule" or "fair representation," that all deviations beyond some small percentage should be deemed bad. To put it another way, if numbers alone are important, how can any deviation above a miniscule I or $2 \%$ be justified? In the majority of states and counties, to get below a $25 \%$ or $15 \%$ deviation will require cutting some political subdivision lines. If some must be cut, why not cut freely and move from a $15 \%$ to a ro or 5 or $r \%$ deviation? In short, there is a real danger, flowing naturally from the tactics of the struggle and the desire to get a set of districts that will not be nullificd on appeal, that the "mathematical exactness or precision" ( 377 U.S. 577) which the Court said was "hardly a workable constitutional requirement" (ibid.) may become the only admissible criterion. See further discussion in Dixon, Reapportionment in the Supreme Court and Congress: Constitutional Struggle for Fair Representation, 63 MrCH. L. REv. 209 (1964).

${ }^{18}$ Supra note 44 , at 30-3I, manuscript opinion.

17 Id. at 29.

18 I32 N.W.2d 249 (Wis. 1965).

10 District Court for the Southern District of New York, Feb. I, r965, unreported.

See also the recent developments in California stemming from a 1963 decision in which a reapportionment duty was found in state law, Grifin v. Board of Supervisors of Montercy County, 60 Cal. 2d 3I8, 33 Cal. Reptr. Ior, 384 P.2d 421 (1963), compliance action reviewed and sustained in 6o Cal. $2 \mathrm{~d} 75 \mathrm{r}$, 36 Cal. Reptr. 6r6, 388 P.2d 888 (1964), discussed in Gallagher, Apportionment in California Counties:

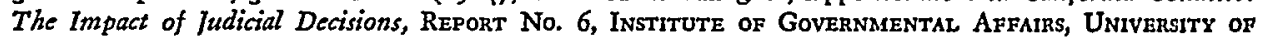
California at Davis ( 1964 ). 
residence requirement, combined with unequal population among the residence or "representation" districts, materially narrow the availability of candidates and lessen the freedom of choice of the county-wide electorate. ${ }^{50}$

Second, the practice of at-large election itself, although not unconstitutional on its face, is subject to challenge under a new Supreme Court ruling, Fortson $v$. Dorsey, ${ }^{51}$ if it can be shown that the winner-take-all characteristic of the at-large election operates regularly to submerge identifiable minority interests. In the Dorsey case the Supreme Court rejected a challenge to Georgia's system of electing seven state senators at-large from Fulton County (Atlanta) for lack of proof of inequity. But, in a dictum suggesting that the Court may move from a wholly arithmetic approach to a "representation" approach to apportionment and districting, the Court said: ${ }^{52}$

It might well be that, designedly or otherwise, a multi-member constituency apportionment scheme, under the circumstances of a particular case, would operate to minimize or cancel out the voting strength of racial or political elements of the voting population. When this is demonstrated it will be time enough to consider whether the system still passes constitutional muster.

In short, by judicial fiat, and as a totally unexpected by-product of the original state legislature reapportionment suit from Tennessee in 1962 , we may soon have at hand a ready-made political instrument for "metro" development, in the form of reinvigorated county government, that probably could not have been developed in a generation of popular referenda. A county board on which all sections of the county -city, suburban, rural-are represented approximately in proportion to their population, could be a ready-made "metro" instrument. The traditionalist character of the county should ease the path to acceptability.

A county-centered development also would obviate the need to think along the lines of more complex borough or "federal" arrangements. A price of most federal arrangements involving a county and its constituent units is that the constituent units, as a condition of voluntary adhesion to the organization, demand representation on some unit basis beyond their proportion of the population. The drive for "unit" equality rather than numbers equality is as endemic here as in the United Nations, or in the formative period that produced the Unied States Senate. This price of unit representation, whatever its political science implications regarding

\footnotetext{
${ }^{80}$ A lower court in Maryland recently dismissed a bill of complaint raising this question and an appeal was not pressed. Lovell v. Hantske, Circuit Court for Anne Arundel County, Maryland, Oct, 2, I964 (unreported). The bill was to enjoin submission to the voters of a new county charter providing that the seven-member County Council be elected at large but reside in seven districts whose population ranged from approximately 18,000 to approximately 35,000 . The court made an inappropriate analogy to election of some congressmen at large, where of course there is no subdistrict residence requirement, and dismissed the bill without serious discussion of the representation problems posed by the new charter provision.
}

52 379 U.S. 433 (1965), reversing 228 F. Supp. 259 (N.D. Ga. 1964).

Id. at 439. 
"good government," is now apparently unconstitutional under the Reapportionment Decisions, ${ }^{53}$ and need be paid no longer.

However, in order to respond to the challenge, there will be a need in some states to reorganize county government and to expand county home rule powers, as part of the judicially-impelled renascence of the county. This already is sensed in Michigan and New York. In the former the 1965 program of the state association of county supervisors includes consideration of both matters and in the latter the state Office for Local Government, although immediately concerned with county reapportionment, is aware of the larger implications. And significantly, the National Association of Counties, as if anticipating the corollary opportunities and challenges that go along with county board reapportionment, made county home rule the theme for its 1962 meeting and has given it major attention since then. ${ }^{54}$

At the local level, therefore, unlike the state level, reapportionment may be, and probably should be, closely intertwined with larger questions of how to re-design the government structure so that it may better serve its newly homogenized one man-one vote citizenry. County board reapportionment, particularly in those states with a tradition of township organization, is a more complex, more challenging, and potentially more revolutionary process than state legislative reapportionment.

A further reason to look now to the county as the formative instrument for metropolitan programs is the fact that civic energy, particularly for reform, is limited. Much of it necesarily will be expended in the process of county board reapportionment, leaving correspondingly little energy for other local experimentations..$^{55}$

${ }^{23}$ For a contrary "hope," see Weinstein, The Effect of the Federal Reapportionmeme Decisions on Counties and Other Forms of Municipal Government, 65 CoLuM. L. REv. 2I (1965). After noting the difficulties in getting citizen acceptance of federated organizations of metropolitan governments, Professor Weinstein suggests that "the Supreme Court may well find it desirable to allow . . . [unit representation] in metros by accepting rough approximations to population standards." Id. at 37.

E* Nat'l Ass's of Counties, Action Program for Home Rule (1962). For a recent study of the related matter of municipal home rule, see Neil Litriefied., Metropolitan Area Prodlems and Municipal HOME RuLE ( $(962)$. A recent assessment of counties contains this comment: "Instead of dying as the pattern of life that helped create it disappears, the county is becoming an increasingly important unit for provision of social services wanted by what is now essentially an urban public. In metropolitan areas ... it is becoming the principal unit for the provision of area-wide services. It is far more acceptable to the general public than is any other general form of metropolitan government." Cunnues R. Adrian, Governing Our Fifty States and Their Communitres roz (1963). A similar assessment of counties in metropolitan areas is found in Duane Lockard, The Politics of State and Local GovERNMENT I04 (1963): "It is noteworthy that the rise of suburbs has not necessarily sounded the death-knell but rather has invited a re-examination of the potentialities of county government."

${ }^{E s}$ In a paper by Stuart C. Hall given at a National Municipal League local reapportionment workshop in San Francisco, November 1964 , the emergence of the California county as the focal point for solution of areawide problems or the construction of a metropolitan form of government was described as follows:

"Here in California, the Legislature repeatedly has draped the 'metropolitan mantle' on the county's 'shoulder.' Planning and zoning; water conservation, distribution and flood control; out-patient mental health clinics, aid to needy children and medical care for welfare recipients; air and water pollution control; library services; housing and urban renewal; city government by contract with the county; county service areas-to name but a few of the areas of expanded countywide authority to govern irrespective of municipal boundaries given to the board of supervisors.

"In short, the trend in this state has been to focus responsibility for the solution of these problems on the county-to make county government work, and not to create super-mctropolitan (sic) exccpt in 


\section{Conclusion}

Focusing on the two approaches just analyzed-a council of governments and a reapportioned county-as solutions to the problem of metropolitan area reorganization is not meant to disparage the plethora of other approaches available, and listed above. However, few of these other devices have the breadth of purpose and the political feasibility to warrant viewing them as major avenues toward a metropolitan-area-wide government. At best they can be viewed as supportive measures. ${ }^{56}$

By contrast, a reapportioned county board, with enlarged powers and prestige commensurate with metropolitan responsibilities, would be a true metropolitan government. A council of governments, operating both as an action agency and as an agency to educate local legislators to think in regional terms, can be a natural stepping stone to a more effective area redistribution of power either within the county or among counties. As a constitutionalizing process, the potential steppingstone role of the council may be viewed as roughly analogous to the similar role of the pre-1787 American Confederation which culminated in the re-centralization of power which we have known since that date as the American Union.

We tend to proliferate governmental forms as we proliferate surplus crops, and without even the need for a subsidy. Particularly in regard to local governments we have been, in the words of Robert Buchanan,

A race that binds

Its body in chains and calls them Liberty, And calls each fresh link Progress.

It is time perhaps now to diminish the number and increase the strength of our local government links and to forge the big link of metropolitan government in the interest of achieving both the resources for Progress and the pinpointed responsibility that preserves Liberty.

very limited areas, e.g., air and water pollution and rapid transit. Resistance to multi-purpose super agencies is determined. They are widely condemned as 'evil' and a 'threat' to, and common enemy of, the autonomy of the cities and counties. The 'home rule county; it is said, has been doing, is doing and should do, the major part of regional government, cancelling 'any need for the controversial and revolutionary idea of metropolitan supergovernment as a third and new level of local government.' The California Legislature has expressed its skepticism of any multi-purpose 'metro' plan. Their answer: the 'urban county': reorganized under an administrative officer with more equitable representation on the county board for the urban populace."

${ }^{\circ}$ For example, improved intergovernmental relations will always be important, and have been called the "hidden dimension" in government. Senator Edmund S. Muskie, Chairman, U.S. Senate Subcommittee on Intergovernmental Relations, Subcommittee Report on INTERgovernmental RelaTroNs ro (1963). But there must also be viable power centers among which effective relations can develop.

Similarly, in regard to planning, a recent survey found that most planning agencies have insufficient areal jurisdiction and insufficient power-and those with the least power are those which have fairly broad areal jurisdiction. U.S. Senate Subcomm. on Intergovernmental Relations, National Survey of Metropolitan Planning ( $\mathrm{Ig}_{3} \mathrm{6}_{3}$ ). The World Health Organization declared in a recent report that, next to world peace, metropolitan planning is the most serious single problem for the next half century. Even as a U.N. agency it properly should have added-" "and effective governmental implementation." 